\title{
Konstruksi Pemberitaan Kebakaran Hutan dan Lahan pada Tribun Jambi
}

\author{
Elfride Isai Maranatha dan Ika Merdekawati Kusmayadi \\ PT. Sinar Sentosa Primata, Jambi \\ E-mail: elfrideisai@gmail.com
}

\begin{abstract}
Forest and land fires are a severe issue in Indonesia today. The mass media has a significant role in presenting information needed by society. This study seeks the construction of the forest, and land fire coverage carried out by the Jambi Tribune and analyzed using the Robert M. Entman frame analysis. The results of this study indicate that in define problems, the Jambi Tribune saw that the issue of forest and land fires was difficult to extinguish due to the widespread fires. In diagnosing the causes of the problem, Tribun Jambi saw that the factor of reduced rainfall supported by the actions of the community and companies that continued to burn the land. In making a moral judgment, Jambi Tribune led readers to assess the government positively by providing information related to actions taken by the government in extinguishing hotspots. In writing the treatment recommendation, Tribun Jambi said that law enforcement needs to be carried out by the government as firmly as possible so that forest and land fires do not happen again. In conclusion, in framing the news, the Jambi Tribune has not been balanced, more inclined to the government. The researcher suggests that the media be able to turn all aspects involved in the problem into a resource in reporting.
\end{abstract}

Keywords: construction of reality, fire land and forest, local media, news framing analysis

\begin{abstract}
Abstrak
Kebakaran hutan dan lahan merupakan isu yang serius di Indonesia saat ini. Media massa mempunyai peran strategis dalam menyajikan informasi yang dibutuhkan oleh masyarakat. Penelitian ini ingin mengetahui konstruksi pemberitaan karhutla yang dilakukan Tribun Jambi dan dianalisis menggunakan analisis bingkai model Robert M. Entman. Hasil penelitian ini menunjukkan dalam mengidentifikasi masalah, Tribun Jambi melihat masalah kebakaran hutan dan lahan sulit dipadamkan karena titik api yang terus yang meluas. Dalam memperkirakan penyebab masalah, Tribun Jambi melihat bahwa faktor berkurangnya curah hujan didukung dengan tindakan masyarakat dan perusahaan yang terus membakar lahan. Dalam membuat keputusan moral, Tribun Jambi menggiring pembaca untuk menilai pemerintah secara positif, dengan memberi informasi terkait tindakan yang dilakukan pemerintah dalam memadamkan titik-titik api. Dalam menuliskan penekanan penyelesaian, Tribun Jambi menyampaikan bahwa penegakan hukum perlu dilakukan pemerintah setegas-tegasnya agar kebakaran hutan dan lahan tidak terjadi lagi. Simpulannya dalam membingkai berita, Tribun Jambi belum berimbang, lebih condong ke pemerintah. Peneliti menyarankan agar media mampu menjadikan semua aspek yang terlibat dalam permasalahan menjadi narasumber dalam pemberitaan.
\end{abstract}

Kata kunci: analisis bingkai, jurnalisme bencana, jurnalisme lingkungan, kebakaran hutan dan lahan, media lokal

\section{PENDAHULUAN}

Indonesia merupakan negara yang termasuk ke dalam rawan bencana, salah satunya kebakaran hutan dan lahan (karhutla). Pada tahun 1997/98, Indonesia mengalami kebakaran

Korespondensi: Elfride Isai Maranatha, S.I.Kom, PT. Sinar Sentosa Primata Jl. Kolonel Abunjani No.9 Selamat Kec. Telanaipura Kota Jambi Provinsi Jambi 36129, Alamat Email: elfridesai@gmail.com

Menyerahkan: Oktober 2019, Diterima: Januari 2020, Terbit: Januari 2020

ISSN: 2549-0559 (cetak), ISSN: 2549-1946 (online), Website: http://jurnal.unpad.ac.id/kajian-jurnalisme 
hutan yang paling parah di seluruh dunia, dan dinyatakan sebagai salah satu bencana lingkungan terburuk sepanjang abad (Tacconi, 2003). Sejak itu, Karhutla kerap terjadi di Indonesia setiap tahunnya, khususnya pada musim kemarau dan dipandang sebagai bencana regional dan global (Suryani, 2012, p. 60)

Kebakaran hutan dan lahan adalah suatu keadaan hutan dan lahan dilanda api, sehingga mengakibatkan kerusakan yang menimbulkan kerugian ekonomis dan atau nilai lingkungan (BNPB, 2017). Selama 2019, hingga September tercatat 857.756 hektar yang terdiri dari 630.451 hektar lahan mineral dan 227.304 hektar di gambut. Angka ini naik meningkat 160\% jika dibandingkan luasan Agustus lalu, sekitar 328.724 hektar (Nugraha, 2019)

Kebakaran hutan dan lahan seringkali menyebabkan bencana asap yang dapat mengganggu aktivitas dan kesejahteraan masyarakat sekitar, hingga ke negara-negara tetangga seperti Singapura, Malaysia dan Brunei Darussalam (Desri, 2016). Provinsi Jambi menjadi salah satu daerah yang rutin dilanda bencana tersebut. Kebakaran hutan dan lahan (karhutla) dipicu oleh musim kemarau serta dapat mendatangkan bencana lain, yakni bencana kabut asap. Pada pertengahan tahun 2017 kebakaran hutan dan lahan (karhutla) kembali terjadi di Provinsi Jambi, sekitar Juli hingga September 2017 menjadi puncak terjadinya kebakaran tersebut. Kebakaran hutan dan lahan (karhutla) yang terjadi memang tak separah tahun 2015, tetapi kebakaran tersebut dapat memicu kabut asap.

Dampak dari karhutla yang tidak terkendali, mengakibatkan kabut asap berbahaya dalam jumlah yang relatif besar. Tercemarnya udara ini ditandai dengan tingginya kadar ISPU (Indeks Standar Pencemaran Udara) di beberapa daerah, terutama di pulau Sumatera yang merupakan ancaman serius bagi kesehatan. Penyakit yang sering disebabkan oleh kabut asap adalah infeksi saluran pernafasan atas, asma penyakit paru obstruktif kronik, penyakti jantung, dan iritasi (DW, 2015). Jambi juga menjadi satu dari beberapa provinsi yang mengalami permasalahan infeksi saluran pernafasan akut (ISPA) akibat dari kebakaran hutan dan lahan tersebut.

Data yang dipublikasikan oleh Pusat Data dan Informasi Kementerian Kesehatan RI (InfoDATIN, 2015) menunjukkan bahwa jumlah kasus ISPA akibat asap pada Juli hingga Oktober di Pulau Sumatera semakin meningkat. Provinsi Jambi pada data tersebut ditunjukkan sebagai daerah tertinggi untuk jumlah kasus ISPA, meskipun di bulan Oktober jumlah kasusnya menurun.

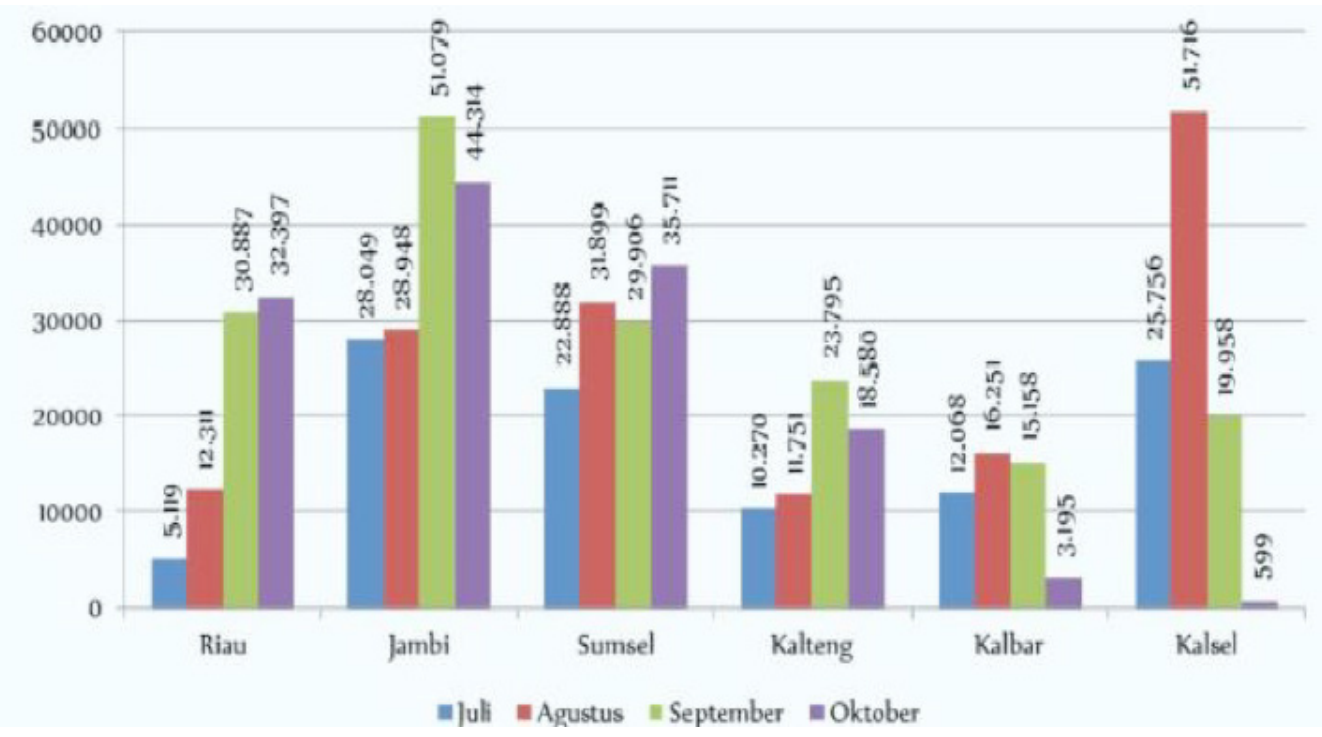

Gambar 1. Jumlah Kasus ISPA Periode Juli hingga Oktober 2015 Sumber: (InfoDATIN, 2015) 
Provinsi Jambi juga ditetapkan sebagai daerah dengan status kadar ISPU keempat tertinggi setelah Kalimantan tengah, Riau dan Sumatera Selatan (Kemenkes RI, 2016), data ini juga diperkuat oleh data dari Kementrian Lingkungan Hidup dan Kehutanan Republik Indonesia (KLHK RI), yaitu Provinsi Jambi berada di urutan ketiga sebagai Provinsi di Pulau Sumatera sebagai wilayah yang rutin mengalami kebakaran hutan dan lahan (Nugraha, 2019).

Kasus karhutla ini sangat sulit dihindari karena lahan-lahan yang terbakar di Provinsi Jambi didominasi oleh lahan gambut. Pada kondisi alami, lahan gambut tidak mudah terbakar gambut itu sifatnya menyerap dan menahan air secara maksimal, seperti spons. Namun, saat kemarau dan mengering gambut sangat mudah terbakar dan mengakibatkan asap hitam tebal. Dan jika sudah terbakar, api di lahan gambut menjadi sulit dipadamkan bahkan hingga berbulanbulan lamanya, biasanya dapat mati total setelah adanya hujan yang cukup intensif sehingga kebakaran dapat berlangsung pada waktu yang lama dan mudah untuk meluas (Pujiono, 2015; Walhi Jambi, 2016).

Isu kebakaran hutan dan lahan di Indonesia menjadikan pemberitaan sebuah bencana mempunyai nilai berita yang sangat tinggi. Media massa mempunyai peran yang sangat strategis sesuai dengan salah satu fungsinya, yaitu fungsi Informasi. Qudratullah menyampaikan bahwa media massa mempunyai kontribusi yang signifikan terhadap kehidupan manusia dan menyatakan bahwa fungsi terpenting pada komunikasi massa adalah fungsi informasi (2016). Seiring dengan perkembangan teknologi informasi dan komunikasi, fungsi informasi sangat diperlukan oleh masyarakat, tidak terkecuali informasi tentang bencana (Qudratullah, 2016, p. 44). Informasi kondisi pra bencana, saat terjadi bencana, maupun pasca bencana akan sangat bermanfaat bagi masyarakat. Asteria menuturkan informasi rutin yang diberikan oleh media adalah sebuah system peringatan dini (early warning system) bagi masyarakat pada umumnya, khususnya sebagai pengingat bagi masyarakat yang berada di wilayah rawan bencana. Sehingga mereka lebih siap ketika menghadapi bencana (Asteria, 2016). Rutinnya pemberitaan atau informasi oleh media massa sangat dapat mengurangi kepanikan masyarakat dari rumor atau isu-isu yang tidak benar dan tidak jelas mengenai kondisi bencana.

Peran dan keterlibatan media dalam memberikan informasi dan mengedukasi masyarakat yang berdampak positif dalam meningkatkan kesadaran masyarakat melalui pemberitaan tentang bencana alam menjadi menarik untuk diteliti. Pemberitaan tentang lingkungan perlu dibahas secara terus menerus agar dampaknya sampai ke semua lapisan masyarakat (Yanuary \& Gumilar, 2018). Tribun Jambi adalah salah satu media lokal di Jambi yang gencar memberitakan kebakaran hutan dan lahan. Media Harian Pagi Tribun Jambi dapat dikatakan adalah media baru, namun Tribun Jambi berhasil menjadi koran dengan penampilan terbaik di wilayah Sumatera selama lima tahun berturut-turut dengan memperoleh penghargaan dari Indonesia Prints Media Awards (IPMA) (Tribun Jambi, 2017). Selain itu, Tribun Jambi mempunyai rubrik daerah yang memungkinkan pembaca untuk dapat memperoleh informasi yang lebih detail, karena pada setiap rubrik daerah terdapat wartawan yang ditempatkan di daerah-daerah yang merupakan daerah sebaran titik api.

Harian lokal Tribun Jambi ini mengangkat pemberitaan soal kebakaran hutan dan lahan (karhutla) dengan memberikan gambaran kondisi kebakaran hingga bagaimana pemerintah dalam proses memadamkan api. Tak hanya itu, Tribun Jambi juga berupaya untuk mengingatkan pemerintah dalam penegakan hukum yang optimal agar kebakaran hutan dan lahan (karhutla) tidak kembali terjadi di waktu mendatang. Dalam setiap pesan yang disampaikan dalam sebuah pemberitaan, terdapat motif atau nilai-nilai yang dibangun oleh media untuk ditanamkan pada khalayaknya (Tamburaka, 2013, p. 85). Seperti pada pemberitaan berjudul Heli Padamkan Api di Tebo yang dimuat oleh Tribun Jambi pada 25 Juli 2017 menyebutkan bahwa kebakaran 
hutan dan lahan (karhutla) semakin meluas di Provinsi Jambi karena kurangnya intensitas hujan. Bukan saja faktor cuaca, tetapi perilaku manusia juga menjadi pemicu muncul titik-titik api. Agar dapat terhindar dari bencana kabut asap seperti yang terjadi pada tahun 2015 maka pemerintah diharapkan mampu menjinakkan api.

Menurut keterangan dari pihak redaksi, kebakaran hutan dan lahan (karhutla) yang terjadi di tahun 2017 tak separah tahun 2015. Akan tetapi, ini harus mendapatkan perhatian bukan hanya satu atau dua pihak, melainkan dari banyak pihak agar pemerintah dapat optimal mengatasinya. Hal itu menjadi pemicu redaksi menempatkan isu ini pada halaman pertama, meskipun berita tersebut merupakan berita lokal yang biasanya terdapat di rubrik daerah.

Media massalokal perlu dibentuk sebagai sarana pemenuhan informasi bagi masyarakat. Susanto menyebutkan sebagai institusi penyedia informasi, media menjadi pusat perhatian publik, secara khusus pada berbagai peristiwa bencana yang terjadi di Indonesia (Susanto et al., 2011, p. 34). Secara positif media bisa menjadi sumber pertama yang memberi informasi peristiwa, menunjukkan perkembangan dan secara psikologis mendorong rasa kemanusiaan publik dan atau menjadi mediator bantuan bencana. Dapat diartikan, media mampu membantu masyarakat baik dalam tindakan pra-bencana, saat bencana, hingga pasca bencana.

Pemberitaan-pemberitaan yang dilaporkan adalah proses dari konstruksi realitas. Hall dalam (Tamburaka, 2013, p. 85) menilai bahwa pesan yang disampaikan oleh jurnalis di media massa kepada pembaca sebenarnya bukan fakta yang sesungguhnya, melainkan para jurnalislah yang dalam menyampaikan beritanya menggunakan strategi pembingkaian melalui pemilihan kata-kata yang terbatas. Jurnalis tersebut telah mengostruksi fakta yang dilihatnya, melalui kategori dan ideologi media mereka.

Beberapa penelitian yang telah dilakukan terkait Kebakaran Hutan dan Lahan cukup banyak, namun masih sedikit yang meneliti tentang pemberitaan Karhutla di Media Massa Nasional maupun Lokal. Penelitian yang dilakukan oleh Harist Adi Nursanto yang berjudul “Analisis Wacana Isu Kebakaran Hutan dan Lahan Indonesia di Media Massa” menunjukkan bahwa dari sisi penanggulangan mengenai isu kebakaran hutan dan lahan, media massa dan peraturan pemerintah telah sejalan. Namun, mengenai pencegahan, penyebab, dan dampak dari kebakaran hutan dan lahan masih tidak sejalan. Bahkan, penelitian Nursanto menyarankan media sebaiknya memberikan informasi mengenai pencegahan dan meningkatkan kesadaran masyarakat untuk mengurangi terjadinya kebakaran hutan dan lahan (Nursanto, 2016). Berbeda dengan penelitian yang dilakukan oleh Istiqomah dengan judul "Pengaruh Pemberitaan Bencana Alam di Harian Serambi Indonesia Terhadap Kesedaran Masyarakat", bahwa media mempunyai peran yang signifikan terhadap tingkat kesadaran masyarakat akan informasi mengenai bencana alam, dan penelitian ini menunjukkan bahwa pemberitaan bencana alam di harian Serambi Indonesia tersebut mempunyai pengaruh positif terhadap kesadaran masyarakat (Istiqomah, 2019).

Tribun Jambi merupakan media cetak lokal yang rutin mengawasi perkembangan kebakaran hingga melakukan pendalaman isu dalam beberapa liputannya. Tribun Jambi rutin memberitakan dari jumlah titik api yang bertambah, jumlah bombing yang sudah dijatuhkan hingga pemberian terkait tersangka pembakaran hingga hukuman yang diberikan kepada tersangka. Hal tersebut semakin memperjelas bahwa media massa berbasis lokal mempunyai peran penting dalam menyampaikan beragam peristiwa yang terjadi di wilayah media tersebut. Melalui media, beragam informasi dapat disampaikan secara luas pada masyarakat.

Sering terjadi, berita diliput dan dilaporkan media, hanya serpihan-serpihan fakta yang belum berbicara. Tugas media adalah membuat fakta yang seolah membisu itu menjadi dapat bicara sendiri kepada khalayak pembaca, pendengar, atau pemirsa dalam bahasa yang enak dibaca 
dan mudah dicerna (Sumadiria, 2010, p. 75). Merujuk pada Eriyanto, berita merupakan finalisasi dari proses yang kompleks dengan peristiwa dan tema yang sudah ditentukan dalam satu kategori (2012, p. 119) dimana prosesnya berita tersebut direkonstruksi berdasarkan suatu kejadian yang diterima, dirasakan, dilihat dan didengar lalu dituliskan oleh jurnalis (Siregar, 1998, p. 19).

Merujuk pada konsep berita tersebut, maka menarik untuk diketahui bagaimana Tribun Jambi sebagai media massa menerapkannya. Menurut Eriyanto, dalam analisis framing, yang dilakukan adalah melihat bagaimana media mengkonstruksi realitas (Eriyanto, 2012, p. 7). Analisis framing membedah cara-cara atau ideologi media saat mengkonstruksi fakta. Analisis ini mencermati strategi seleksi, penonjolan, dan pertautan fakta ke dalam berita agar lebih bermakna, lebih menarik, lebih berarti atau lebih diingat, untuk menggiring interpretasi khalayak sesuai perspektifnya (Afdiningsih, Sihabudin, \& Praceka, 2017).

Proses konstruksi realitas pada dasarnya merupakan suatu upaya untuk menceritakan sebuah peristiwa atau kejadian yang berkaitan dengan politik merupakan suatu usaha mengkonstruksi realitas. Namun konstruksi media itu sendiri terbentuk dari wartawan yang melihat sebuah kejadian dimasyarakat dengan apa yang sebenarnya terjadi dan bukan merupakan sebuah rekayasa, karena dalam menulis sebuah realitas wartawan mempunyai sikap yang berimbang. Sikap berimbang tersebut meliputi (1), berita yang ditulis sesuai dengan realitas dan tidak condong pada satu pihak. (2), wartawan bersikap objektif, tidak memasukkan asumsi atau opini pribadi pada sebuah pemberitaan (Eriyanto, 2012, p. 30). Sehingga, penelitian ini bertujuan untuk mengetahui bagaimana konstruksi pemberitaan kebakaran hutan dan lahan pada Tribun Jambi?

\section{METODE}

Metode pembingkaian yang digunakan dalam penelitian ini dikembangkan oleh Robert M. Entman. Dalam metodi ini, Entman melihat pembingkaian dalam dua dimensi besar, yaitu seleksi isu dan penekanan atau penonjolan aspek-aspek realitas. Kedua faktor ini dapat dilihat melalui proses penekanan isi beritanya (Eriyanto, 2012, pp. 221-222).

Pembingkaian Karhutla menjadi isu yang tidak memiliki batas waktu dan kontroversial. Masalah penelitian terkait bagaimana Tribun Jambi membingkai suatu realitas karhutla dapat dilihat dari bagaimana proses seleksi dari isu dan penekanan. Tujuan penelitian ini antara lain: (1). Mengetahui bagaimana Tribun Jambi mendefinisikan masalah (define problems) dalam memberitaan kebakaran hutan dan lahan (karhutla). (2). Mengetahui bagaimana Tribun Jambi memperkirakan masalah (diagnose causes) dalam memberitakan kebakaran hutan dan lahan (karhutla). (3). Mengetahui bagaimana Tribun Jambi membuat keputusan moral (make moral judgment) dalam memberitakan kebakaran hutan dan lahan (karhutla). (4). Mengetahui bagaimana Tribun Jambi menekankan penyelesaian (treatment recommendation) dalam memberitakan kebakaran hutan dan lahan (karhutla).

Guna menjawab berbagai pertanyaan peneliti tersebut, maka metode yang digunakan dalam penelitian adalah metode pembingkaian. Metode ini digunakan karena berfungsi untuk mengetahui perspektif atau cara pandang yang digunakan wartawan ketika menyeleksi isu dan menulis berita. Cara pandang atas perspektif tersebut selanjutnya terkait pada fakta apa yang diambil, bagian mana yang ditonjolkan dan dihilangkan, serta hendak dibawa ke mana berita tersebut.

Data utama pada penelitian ini adalah halaman pertama Harian Pagi Tribun Jambi edisi Juli - September 2017 yang diperoleh melalui dokumentasi pihak redaksi juga diakses secara online dan dikliping sebagai data penelitian. Lalu, setelah teks berita diperoleh, dilakukan 
analisis bingkai dengan langkah pertama menganalisis suatu teks atau agenda pemberitaan yang dibentuk oleh media, yaitu mengidentifikasi dan memahami masalah, sehingga pada akhirnya memahami tindakan media yang memutuskan untuk mengangkat persoalan tersebut ke depan khalayak. Langkah kedua, membingkai siapa aktor penyebab masalah. Peristiwa itu dilihat disebabkan oleh apa, apa yang dianggap sebagai penyebab dari suatu masalah.

Setelah dua tahapan tersebut, Entman juga mengurai moral evaluation dibalik berita, yaitu proses telaah yang dilakukan untuk merumuskan landasan pembenaran atau argumentasi secara moral demi menguatkan struktur gagasan yang telah dibangun. Gagasan tersebut menurut Etnman harus berhubungan secara emosional dengan khalayak. Terakhir treatment recommendation, yaitu tahapan merumuskan kehendak akhir dari seorang jurnalis atau media untuk menuntaskan sebuah peristiwa. Dan untuk mendapat pemahaman tentang penetapan standar pemberitaannya, wawancara pun dilakukan terhadap korrdinator liputan, serta wartawan yang menulis berita yang diteliti pada Harian Pagi Tribun Jabar.

\section{HASIL DAN PEMBAHASAN}

Penelitian ini membahas pembingkaian Tribun Jambi terhadap realitas kebakaran hutan dan lahan (karhutla) yang terjadi di Provinsi Jambi. Pembingkaian ini mencuat ke permukaan memasuki bulan Juli hingga September 2017. Fokus penelitian ini pada enam berita terkait karhutla yang dijadikan laporan utama.

Tabel 2. Berita-Berita yang Dianalisis

\begin{tabular}{|r|l|l|}
\hline \multicolumn{1}{|c|}{ No } & \multicolumn{1}{|c|}{ Tanggal } & \multicolumn{1}{c|}{ Judul } \\
\hline 1. & 25 Juli 2017 & Heli Padamkan Api di Tebo \\
\hline 2. & 30 Juli 2017 & Kebakaran Merembet ke Tanah Gambut \\
\hline 3. & 4 Agustus 2017 & 4 Jam Padamkan Api \\
\hline 4. & 6 Agustus 2017 & Siap Mengganti Kapolda \\
\hline 5. & 8 Agustus 2017 & Pembakar Diupah 2 Juta \\
\hline 6. & 17 September 2017 & Terancam fenda 10M \\
\hline
\end{tabular}

Sumber: Peneliti, 2018

Berdasarkan pengamatan, berita di Tribun Jambi mengutarakan nilai berita terkait kedekatan geografis dan kedekatan psikologis. Kedekatan geografis merujuk pada suatu peristiwa di sekitar tempat tinggal. Sementara kedekatan psikologis lebih banyak ditentukan oleh tingkat keterikatan pembaca secara psikologis dalam memahami suatu peristiwa atau berita, baik pikiran, perasaan, dan kejiwaan orang tersebut (Sumadiria, 2010, pp. 80-92). Berita ini juga memiliki unsur nilai berita lainnya, seperti keluarbiasaan (jumlah titik api terus bertambah), akibat (bencana kabut asap bisa saja kembali menghampiri Provinsi Jambi hingga mancanegara), ketertarikan manusia (human interest) pemadaman yang dilakukan pemerintah dengan mengeluarkan biaya yang besar menunjukkan upaya pemerintah dalam menghindari bencana kabut asap yang bisa terjadi.

Nilai berita lainnya adalah aktual. Sumadiria juga menyebutkan bahwa nilai berita aktual terdiri dari tiga yakni aktualisasi kalender, aktualisasi waktu dan aktualisasi masalah (Sumadiria, 2010). Kebakaran hutan dan lahan (karhutla) tergolong memiliki nilai aktualisasi waktu. Peristiwa yang baru terjadi, keesokan harinya langsung diberitakan. Sementara terkait isu pembakaran lahan sendiri memiliki nilai aktualisasi masalah. Pasalnya, isu pembakaran lahan adalah isu yang tak pernah ada habisnya.

Penelitian ini menggunakan paradigma konstruksionis, yakni paradigma penelitian yang menganggap sebuah realitas kehidupan sosial adalah hasil pembentukan atau konstruksi, 
sehingga yang muncul bukan realitas secara alamiah. Penelitian ini mengambil metodologi secara kualitatif dengan desain penelitian deskriptif, dengan teknik analisis bingkai. Eriyanto (2012, p. 3) menyebutkan bahwa analisis bingkai merupakan sebuah analisis untuk mengetahui bagaimana realitas dibingkai oleh media. Pembingkaian ini dikembangkan atau dibangun dengan pemaknaan tertentu sesuai dengan pemahaman redaksi atau sang penulis, yakni wartawan itu sendiri. Hasil dari konstruksi berita itu sendiri akan menggunakan orang-orang tertentu sesuai dengan pemahaman mereka untuk dijadikan narasumber dalam berita.

Analisis ini menjadi kajian tentang bagaimana naskah berita dibentuk oleh media. Tak hanya itu, analisis ini turut mengkaji bagaimana wartawan mengkonstruksi peristiwa danmenyajikannya kepada khalayak pembaca. Analisis ini digunakan untuk membedah cara atau ideologi media mengkonstuksi fakta. Menganalisis strategi seleksi, penonjolan dan pertauan ke dalam berita sehingga lebih bermakna, menarik, berarti atau lebih diingat, untuk menggiring interpretasi khalayak sesuai dengan prespektifnya (Sobur, 2009, pp. 162-163) . (Sobur, 2009:162-1630).

Entman dalam (Eriyanto, 2012, p. 227) mengungkapkan ada empat elemen penting dalam penelitian dalam menganalisis teks berita. Elemen tersebut adalah pendefinisian masalah (define problem), memperkirakan sumber masalah (diagnose causes), membuat keputusan moral (make moral judgement), penekanan penyelesaian (treatment recommendation) .

Pada berita Heli Padamkan Api di Tebo, 25 Juli 2017. Secara garis besar memberitakan tentang peringatan terjadinya kebakaran hutan dan lahan (karhutla). Di mana titik hotspot semakin meningkat dan mengancam adanya bencana lain, yakni bencana kabut asap. Pendefinisian masalah pada berita ini adalah Tribun Jambi menjelaskan titik api yang terus bertambah dan dapat mengakibatkan kabut asap. Tribun Jambi memperkirakan penyebab masalah karena titik hotspot terus bertambah akibat ulah korporasi yang terus membakar lahan dan intensitas hujan yang terus berkurang.

Make Moral Judgement pada berita ini menunjukkan pemerintah bergerak cepat dalam memadamkan api. Treatment Recommendation pada berita ini adalah mengingatkan pemerintah untuk berlaku tegas kepada masyarakat dan perusahaan yang membakar lagan baik melalui teguran hingga pencabutan izin pengelolaan lahan.

Berita yang diteliti selanjutnya berjudul Kebakaran Merembet ke Tanah Gambut, 30 Juli 2017. Secara garis besar berita membahas terkait api yang semakin meluas hingga ke wilayah gambut dan sulit untuk dipadamkan. Define Problems pada berita ini adalah api merembet ke tanah gambut dan sulit untuk dipadamkan. Diagnose Causes berita ini adalah kegiatan warga yang terus melakukan pembakaran lahan. Make Moral Judgement pada berita ini berupaya menunjukkan bahwa pemerintah sudah bergerak cepat memadamkan api.

Berita selanjutnya dengan judul 4 Jam Padamkan Api di Tebo, 4 Agustus 2017. Define Problems pada berita ini adalah pemerintah mengalami kesulitan memadamkan api. Diagnose Causes berita ini menunjukkan pemadaman menjadi sulit dilakukan karena kebakaran terjadi di wilayah gambut akibat ulah masyarakat dan korporasi. Make Moral Judgement, berkaitan dengan upaya yang dilakukan pemerintah dalam memadamkan api, baik dari jalur darat hingga udara menggunakan helikopter. Treatment Recommendation dalam berita ini mengingatkan pemerintah untuk bertindak tegas pada korporasi yang melakukan pembakaran hutan dan lahan.

Berita selanjutnya, Siap Mengganti Kapolda, 6 Agustus 2017. Berita ini menjelaskan satu dari sekian banyak agenda Jendral Tito Karnavian adalah mengevaluasi tim dalam menanggulangi kebekaran hutan dan lahan (karhutla) di Provinsi Jambi. Menegaskan kepada tim untuk mengoptimalkan upaya dalam menyelesaikan kasus ini. Bahkan, memberi "ancaman" kepada kapolda dan kapolres untuk diganti jika mereka ternyata tak bisa menyelesaikan. Define 
Problems dalam berita ini adalah Tribun Jambi menilai bahwa kebakaran hutan dan lahan (karhutla) yang terjadi di Jambi menjadi bahasan penting Kapolda Tito Karnavian di Jambi. Diagnose Causes berita ini terkait agenda penting karena Kapolri ingin mengevaluasi serta memberikan amanat kepada pemerintah Provinsi Jambi untuk serius mengatasi karhutla. Treatment Recommendation dalam berita ini adalah mengingatkan Pemerintah Daerah dan Satgas Karuhtla untuk bekerjsama dalam mengatasi karhutla. Pemda memperkuat mekanisme pertanian dan Sargas bertugas meminimalisir kebakaran.

Berita selanjutnya berjudul Pembakar Diupah 2 Juta, 8 Agustus 2017. Define Problems dalam berita ini adalah kebakaran hutan dan lahan (karhutla) dipelopori oleh perusahaan dengan cara mengupah masyarakat. Diagnose Causes, Tribun Jambi menjelaskan bahwa faktor ekonomi adalah penyebab utama masyarakat menerima tawaran dari perusahaan. Make Moral Judgement berita ini berupaya menunjukkan tindakan pemerintah yang cepat dalam mengatasi titik-titik api yang muncul. Tribun Jambi dalam Treatment Recommendation berupaya mengingatkan pemerintah untuk lebih tegas pada pelaku pembakaran, baik masyarakat atau perusahaan. Dengan cara mengambil lahan yang dibakar menjadi milik pemerintah.

Berikutnya berita berjudul Terancam Denda 10 M pada 13 September 2017 menjelaskan terkait seorang pelaku yang sudah tertangkap dan menjelaskan lebih lengkap terkait ancaman hukuman yang didapat oleh seorang pelaku pembakaran lahan. Define Problems dalam berita ini berkaitan pada hukuman bagi pelaku pembakaran. Diagnose Causes berita ini menjelasakan hukuman tersebut dapat diberikan karena pelaku pembakaran terbukti melakukan perbutaan pidana, yakni mengelola kawasan hutan tanpa izin Menteri Kehutanan. Make Moral Judgement berita ini adalah menunjukkan upaya yang dilakukan pemerintah dalam memadamkan api. Treatment Recommendation berita ini berkitan pada upaya pemeritah dalam mengingatkan pemrintah berlaku adil pada masyarakat dan perusahaan yang terlibat tindakan pembakaran lahan.

Hasil penelitian ini dibahas dengan sudut pandang seleksi isu, penonjolan aspek tertentu terhadap isu, dan teori konstruksi sosial atas realitas dan teori hirarki pengaruh isi media massa. Dimensi seleksi isu dan penonjolan aspek tertentu terhadap isu merupakan dua perangkat besar dalam pembingkaian yang dikembangkan Robert M. Entman (Eriyanto, 2012, p. 221)

Selain itu, penelitian ini mengggunakan teori konstruksi sosial atas realitas dari Berger dan Luckmann untuk melihat bagaimana suatu realitas sosial dibentuk dan dikonstruksi Teori ini menyebutkan bahwa suatu realitas sosial dibentuk atau dikonstruksi melalui tiga tahapan, yakni eksternalisasi, objektivasi, dan internalisasi (Santoso, 2016, pp. 31-32). Upaya ekternalisasi disebut sebagi bentuk pencurahan ekspresi bentuk diri masnusia ke dalam dunia, secara mental dan fisik. Apabila dikaitkan dengan Tribun Jambi dalam memberitakan kebakaran hutan dan lahan (karhutla), upaya pencurahan terlihat dari sikap redaksi memnadang isu ini adalah masalah serius yang terus berulang setiap tahun.

Kedua, upaya objektivasi bisa dikatakan sebagai penyusunan strategi yang akan dilakukan oleh kedua media yang bersangkutan sebagai bentuk tindak lanjut dari eksternalisasi. Di mana redaksi menentukan kebijakan untuk mengawal masalah kebakaran hutan dan lahan (karhutla). Kebijakan yang dibentuk melalui rapat redaksi atau rapat besar bersama reporter. Tahapan terakhir adalah internalisasi. Di mana fase ini bisa disebut pengaplikasian sikap yang sudah ditetapkan media yang bersangkutan dalam menanggapi realitas sosial. Bentuk realisasi yang dilakukan dengan menempatak berita di halaman pertama, serta rutin memberitakan dua hingga tiga berita dalam sehari.

Peneliti juga mengaitkan pemberitaan ini dengan teori hirarki pengaruh isi pesan media massa. Setiap media menerjemakan suatu realitas dengan konstruksi yang berbeda yang 
disebabkan oleh beberapa faktor. Secara umum terbagi atas faktor internal dan eksternal. Teori yang dikemukakan Shoemaker dan Resse dalam (Tamburaka, 2013, p. 52), menggolongkan media massa tersebut atas pengaruh individu pekerjaan media massa, rutinitas media, pengaruh organisasi, pengaruh luar organisasi, dan ideologi.

Level individu pada media massa bukannya pengalaman kerja di bidang jurnalistik, pengalaman pendididikan dan pelatihan serta faktor personalnya, menjadi pemicu bagaimana sosok wartawan mengkap fakta yang ada. Dikaitkan dengan Tribun Jambi, media ini menekankan pelatihan dengan menyamaratakan pos liputan bagi semua wartawan. Tujuan agar pengetahuan setiap wartawan akan semua desk liputan sama dan tidak ada kedekatan personal reporter dengan narasumbernya.

Faktor rutinitas media menjadi faktor kuat dalam pembentukan pesan di media massa. Ketetapan seperti sudut pandang pemberitaan, kerangka judul, hingga format penyajian berita dibahas dalam rapat redaksi. Sehingga semua berita sesuai dengan standar operasional tugas yang ditetapkan. Proses ini juga mencakup sesi pemotongan berita atau pengubahan format sajian berita. Pada aspek ini, Tribun Jambi menempat isu kebakaran hutan dan lahan (karhutla) karena mengganggap ini adalah perkara besar yang dapat memicu kabut asap.

Level organisasi jadi lapisan lain. Faktor ini dipicu oleh sumber berita, organisasi media itu sendiri dan khalyak. Media massa akan memastikan bahwa berita yang disajikan sesuai dengan sasaran pembaca dan beritanya tidak menyinggung perasaan siapa pun yang berkaitan dengan organiasi media itu sendiri. Terkait dengan berita kebakaran hutan dan lahan (karhutla), Tribun Jambi banyak meminta penjelasan dari pihak pemerintah dan seakan meluapakan suara dari masyarakat. Tribun Jambi terlalu menggebu-gebu memberitakan tindakan pemerintah dalam menjinakkan api.

Lapisan lain yang turut memengaruhi isi adalah kalangan di luar organiasai media massa. Kalangan ini adalah pengiklan, kontrol pemerintah, pembaca, dan pangsa pasar. Peneliti melihat pembaca dan pangsa pasar menjadi dasar lain dari pembuatan berita ini. Mengingat cakupan Tribun Jambi adalah Provinsi Jambi maka berita terkait karhutla ini harus disampaikan kepada masyarakat Jambi.

Masalah ideologi menjadi unsur sentral dalam membentuk pesan di media massa. Ideologi merupakan kerangka berpikir atau kerangka referensi tertentu yang dipaki oleh individu untuk merlihat realitas. Ideologi ini berhubungan dengan konsepsi atau posisi seseorang dalam menafsirkan realitas. Tribun Jambi menaruh perhatian besar terhadap isu ini. Walaupun redaksi tidak mempunyai rubrik khusus untuk lingkungan mereka tetap berupaya mengawasi perkembangan peristiwa dan konsisten dalam memberitakannya.

\section{Seleksi Isu}

Dalam proses analisis pembingkaian ada dua aspek besar, yakni proses memilih fakta dan menulis fakta. Kedua hal tersebut berkaitan dengan isu apa yang akan diseleksi dan ditonjolkan oleh media dalam proses pemberitaan serta menggunakan aspek tertentu untuk mempertegas isu atau realitas. Seleksi isu berhubungan dengan pemilihan fakta, di mana tidak semua aspek dari isu ditampilkan di media masssa. Proses pemilihan fakta ini didasari pada asusmsi dan perspektif wartawan. Hal ini berkaitan dengan bagaimana pemahaman pada suatu peristiwa oleh media massa. Fakta yang sesuai dengan pemahaman media yang bersangkutan akan ditampilkan kepada khalayak, sedangkan yang tidak sesuai dengan pemahaman media cenderung disembunyikan atau bahkan dihilangkan. Melalui pemilihan fakta maka setiap media akan memiliki pemahaman dan konstruksi sendiri terhadap realitas sesuai dengan kepentingan media. 
Berdasarkan enam berita terkait kebakaran hutan dan lahan (karhutla), peneliti meringkas enam fakta telah dipilih Tribun Jambi sebagai dimensi seleksi isu dari realitas kebakaran hutan dan lahan (karhutla) di Provinsi Jambi. Enam fakta tersebut adalah:

1. Fakta bahwa pemerintah sudah melakukan penangan terkait titik-titik api yang terlihat di berbagai wilayah. Baik menggunakan jalur darat hingga jalur udara, bombing.

2. Fakta bahwa pembakaran yang terus menerus dilakukan masyarakat dan juga perusahaan menyebabkan terjadinya kebakaran hutan dan lahan (karhutla) dapat menyebabkan bencana kabut asap di Provinsi Jambi.

3. Fakta bahwa pemerintah sudah berupaya melakukan penegakan hukum pelaku dengan menangkap dan diberikan sanksi denda 10 milyar dan 10 tahun penjara sesuai UndangUndang. Walaupun Tribun Jambi menilai penegakan hukum belum maksimal maka kebakaran hutan dan lahan (karhutla) menjadi sebuah peristiwa yang rutin terjadi.

4. Fakta bahwa pemerintah Provinsi Jambi lewat Kapolri Tito Karnavian diajak untuk lebih maksimal dalam menangani kasus kebakaran hutan dan lahan (Karhutla) yang rutin terjadi di Provinsi Jambi. Dan menegaskan bahwa kebakaran yang terjadi di lakukan oleh masyarakat dan perusahaan.

5. Fakta bahwa faktor ekonomi adalah penyebab utama masyarakat menerima tawaran dari perusahaan.

6. Fakta bahwa karhutla adalah kasus yang perlu ditindak dengan tegas, dan pemerintah dinilai belum berlaku adil pada masyarakat juga perusahaan.

Fakta-fakta tersebut diatas didasari pada asumsi dan perspektif wartawan. Hal ini berkaitan dengan bagaimana pemahaman pada suatu peristiwa oleh media massa. Fakta yang sesuai dengan pemahaman media yang bersangkutan akan ditampilkan kepada khalayak, sedangkan yang tidak sesuai dengan pemahaman media cenderung disembunyikan atau bahkan dihilangkan. Melalui pemilihan fakta maka setiap media akan memiliki pemahaman dan konstruksi sendiri terhadap realitas sesuai dengan kepentingan media. Tabel 3 memaparkan analisis framing pada berita-berita yang diteliti pada penelitian ini.

Tabel 3. Analisis Perangkat Bingkai Robert M. Entman

\begin{tabular}{|l|l|l|l|l|}
\hline $\begin{array}{c}\text { Perangkat } \\
\text { Analisis }\end{array}$ & \multicolumn{1}{|c|}{ Define Problems } & \multicolumn{1}{|c|}{ Diagnose Cause } & \multicolumn{1}{c|}{$\begin{array}{c}\text { Make Moral } \\
\text { Judgment }\end{array}$} & $\begin{array}{c}\text { Treatment } \\
\text { Recommendation }\end{array}$ \\
\hline Berita 1 & $\begin{array}{l}\text { Merilis titik api di } \\
\text { delapan titik }\end{array}$ & $\begin{array}{l}\text { Kurangnya } \\
\text { intensitas hujan dan } \\
\text { pembakaran oleh } \\
\text { koorperasi }\end{array}$ & $\begin{array}{l}\text { Masyarakat perlu } \\
\text { diimbau untuk tidak } \\
\text { membakar hutan }\end{array}$ & $\begin{array}{l}\text { Pemerintah harus } \\
\text { tegas dalam } \\
\text { memberikan sanksi, } \\
\text { mulai dari menegur } \\
\text { hingga mencabut } \\
\text { izin }\end{array}$ \\
\hline Berita 2 & $\begin{array}{l}\text { Kebakaran hutan } \\
\text { meluas ke wilayah } \\
\text { gambut }\end{array}$ & $\begin{array}{l}\text { Warga melakukan } \\
\text { pembakaran lahan } \\
\text { untuk ditanami sawit }\end{array}$ & $\begin{array}{l}\text { Pemerintah berupaya } \\
\text { untuk memadamkan } \\
\text { api }\end{array}$ & - \\
\hline Berita 3 & $\begin{array}{l}\text { Api sulit dipadamkan } \\
\text { Kebakaran terjadi } \\
\text { di wilayah gambut. } \\
\text { Korporasi adalah } \\
\text { pelakunya }\end{array}$ & $\begin{array}{l}\text { Pemerintah berupaya } \\
\text { untuk memadamkan } \\
\text { api }\end{array}$ & $\begin{array}{l}\text { Pemerintah harus } \\
\text { tegas dalam } \\
\text { memberikan sanksi, } \\
\text { mulai dati menegur } \\
\text { hingga mencabut } \\
\text { izin }\end{array}$ \\
\hline Berita 4 & $\begin{array}{l}\text { Kedatangan Kapolri } \\
\text { ke Jambi membahas } \\
\text { karhutla menjadi } \\
\text { agenda penting }\end{array}$ & $\begin{array}{l}\text { Mengevaluasi jajaran } \\
\text { kepolisian daerah } \\
\text { yang menangai } \\
\text { karhutla. Pelaku } \\
\text { pembakaran adalah } \\
\text { masyrakat dan } \\
\text { perusahaan. }\end{array}$ & - & $\begin{array}{l}\text { Pemerintah daerah } \\
\text { dan Satgas Karhutla } \\
\text { perlu bekerjasama } \\
\text { Pemda memperkuat } \\
\text { mekanisme } \\
\text { pertanian. Satgas } \\
\text { meminimalisir } \\
\text { kebakaran }\end{array}$ \\
\hline
\end{tabular}


Volume 03 Nomor 02 Tahun 2020

DOI: $10.24198 /$ jkj.v3i2.23894

\begin{tabular}{|l|l|l|l|l|}
\hline Berita 5 & $\begin{array}{l}\text { Adanya upah yang } \\
\text { diberikan kepada } \\
\text { masyarakat }\end{array}$ & $\begin{array}{l}\text { Masyarakat menerima } \\
\text { upah karena faktor } \\
\text { ekonomi. Pembakara } \\
\text { dilakukan dua hingga } \\
\text { tiga kali seminggu }\end{array}$ & $\begin{array}{l}\text { Pemerintah berupaya } \\
\text { untuk memadamkan } \\
\text { api. }\end{array}$ & $\begin{array}{l}\text { Pemerintah } \\
\text { membuat efek jera } \\
\text { dengan mengambil } \\
\text { lahan yang dibakar } \\
\text { menjadi milik } \\
\text { negara }\end{array}$ \\
\hline Berita 6 & $\begin{array}{l}\text { Hukuman bagi para } \\
\text { pelaku pembakaran }\end{array}$ & $\begin{array}{l}\text { Tersangka diduga } \\
\text { melakukan perbuatan } \\
\text { pidana dibidang } \\
\text { kehutanan yakni } \\
\text { mengelola kawasan } \\
\text { hutan tanpa izin } \\
\text { Menteri Kehutanan }\end{array}$ & $\begin{array}{l}\text { Pemerintah berupaya } \\
\text { untuk memadamkan } \\
\text { api }\end{array}$ & $\begin{array}{l}\text { Pemerintah perlu } \\
\text { bertindak tegas. } \\
\text { Jika perorangan } \\
\text { diberi sanksi. } \\
\text { Jika perusahaan } \\
\text { pelakunya maka } \\
\text { pencabutan } \\
\text { izin perlu juga } \\
\text { dilakukan. }\end{array}$ \\
\hline
\end{tabular}

Sumber; Peneliti, 2018

\section{Penonjolan Aspek Tertentu dari Isu}

Penonjolan aspek tertentu terhadap isu berhubungan dengan penulisan fakta. Ketika aspek tertentu dari suatu peristiwa/isu tersebut telah dipilih, bagaimana aspek tersebut ditulis. Hal ini terkait fakta atau ungkapan untuk menggambarkan realitas yang ingin ditonjolkan. Penonjolan adalah sebuah proses dalam membuat suatu informasi yang lebih bermakna. Realitas yang ditampilkan atau disajikan pada khalayak secara menonjol mampu mencuri perhatian dan berpengaruh besar dalam memahami sebuah realitas. Media dalam praktik pembingkaian menjalani proses seleksi isu dengan mengabaikan isu lain dan menonjolkan aspek tersebut dengan menggunakan strategi seperti menempatkan di headline depan atau bagian belakang pengulangan, pemakian grafis untuk mendukung dan memperkuat penonjolan. Media juga menggunakan pelabelan tertentu untuk menggambarkan orang atau peristiwa yang diberitakan (Eriyanto, 2012, pp. 163-164).

Kata penonjolan didefinisikan sebagai membuat informasi lebih terlihat jelas, lebih bermakna, atau lebih mudah diingat oleh khalayak, lebih terasa dan tersimpan dalam memori dibandingkan dengan upaya yang disajikan secara biasa (Sobur, 2009, pp. 163-164). Upaya penonjolan suatu aspek tersebut berkaitan dengan teori konstruksi realitas sosial.

Jadi dalam pemberitaan ini, isu yang dipilih dan ditonjolkan Tribun Jambi adalah bagaimana pemerintah dalam menangani peristiwa kebakaran hutan dan lahan (karhutla) serta memancing kepedulian masyarakat untuk tidak membuka lahan dengan cara membakar. Kepedulian masyarakat dipancing melalui data-data terkait luas lahan yang terbakar serta ancaman hukuman yang bisa dijatuhkan pada pelaku pembakaran hutan dan lahan.

Tabel 4. Akumulasi Analisis Perangkat Pembingkaian Pemberitaan

\begin{tabular}{|l|l|l|l|}
\hline \multicolumn{1}{|c|}{ Define Problems } & \multicolumn{1}{|c|}{ Diagnose Cause } & Make Moral Judgment & \multicolumn{1}{c|}{$\begin{array}{c}\text { Treatment } \\
\text { Recommendation }\end{array}$} \\
\hline $\begin{array}{l}\text { Titik api terus bertambah } \\
\text { hingga wilayah gambut }\end{array}$ & $\begin{array}{l}\text { Dilakukan oleh } \\
\text { perusahaan dengan cara } \\
\text { membayar masyarakat. } \\
\text { Dapat terjadi karena } \\
\text { kurang tegas penegakan } \\
\text { hukum }\end{array}$ & $\begin{array}{l}\text { Pemerintah terus } \\
\text { berupaya memadamkan } \\
\text { api }\end{array}$ & $\begin{array}{l}\text { Pencabutan izin } \\
\text { milik perusahaan dan } \\
\text { mengambil lahan untuk } \\
\text { negara }\end{array}$ \\
\hline
\end{tabular}

Sumber: Peneliti, 2018

Pada penelitian ini, peneliti menganalisis berita Tribun Jambi yang membahas kebakaran hutan dan lahan (karhutla). Hasil analisis menunjukkan Tribun Jambi memiliki kecenderungan pro terhadap tindakan pemerintah dalam pemadaman api. Penonjolan dari aspek penulisan naskah, pemilihan pertanyaan wawancara pemilihan narasumber, aspek gambar, dan lain-lain 
menjadi dasar peneliti menilai Tribun Jambi memiliki kecenderungan pro. Tribun Jambi lebih banyak mengisahkan proses pemadaman dibandingkan masalah penegakan hukum yang Tribun Jambi sendiri menilai kurang maksimal.

Secara keseluruhan, jika dilihat dari aspek naskah, pertanyaan serta pernyataan narasumber, dan gambar, Tribun Jambi membingkai pemerintah optimal dalam pemadaman api. Oleh sebab itu, bingkai yang muncul pada keenam berita tersebut adalah banyaknya tindakan yang dilakukan pemerintah untuk terhindar dari bencana kabut asap. Pada konteks ini, Tribun Jambi berada pada posisi yang pro terhadap pemerintah. Pada berbagai aspek penonjolan Tribun Jambi menyayangkan penegakan hukum yang belum optimal.

Merujuk pada tabel tabel 4, Tribun Jabar melihat masalah karhutla perlu diberitakan karena titik api yang terus bertambah. Hal ini disebabkan kurangnya curah hujan dan penegakan hukum yang kurang tegas sehingga masyarakat dan koporasi terus membuka lahan dengan cara dibakar. Tribun Jambi melihat pemerintah terus berupaya untuk memadamkantitik api, agar tidak mendatangkan bencana baru, yakni bencana kabut asap. Tribun Jambi menyimpulkan bahwa pencabutan izin milik perusahaan adalah solusi yang bisa memberikan efek jera pada perusahaan. Akan tetapi, peneliti menyayangkan Tribun Jambi hanya lebih memilih penonjolan isu penanggulangan api menjadi berita utama, sedangkan terkait penegakan hukum disajikan menjadi berita pelengkap atau sub berita.

Terlihat bahwa pemberitaan ini tidak mampu membuat keputusan pilihan moral (make moral judgement) kepada masyarakat untuk menjaga alam dan tidak membakar hutan karena pemberitaan hanya terfokus pada tindakan pemerintah dalam memadamkan api. Gambaran bahwa peristiwa ini adalah masalah besar memang tersampaikan, tetapi ajakan untuk berhenti membakar lahan tidak tersampaikan dengan tegas. Menempatkan masalah penegakan hukum pada berita utama setidaknya dapat mencuri perhatian pembaca terkhusus pada pelaku pembakaran, mereka akan merasa was-was dan takut untuk melakukan pembakaran lahan. Pemerintah juga akan merasa bahwa ini adalah masalah besar dan sudah menjadi perhatian banyak pihak.

\section{SIMPULAN}

Berdasarkan hasil analisis dan pembahasan metode pembingkaian model Robert M. Entman. Berita Tribun Jambi terkait kebakaran hutan dan lahan (karhutla) menghasilkan simpulan sebagai berikut: (1). Tribun Jambi mendefinisikan pemberitaan kebakaran hutan dan lahan (karhutla) adalah kasus yang rutin terjadi di Provinsi Jambi. Pemerintah perlu mengatasi titik hotspot yang terus bertambah dan meluas hingga wilayah gambut. Bila dibiarkan, api dapat memicu timbulnya bencana baru, yakni kabut asap seperti yang terjadi saat ini. Hal ini terlihat dari fakta-fakta yang disampaikan oleh Tribun Jambi. Redaksi memaparkan upayaupaya yang dilakukan pemerintah dalam memadamkan api yang terus meluas. (2). Tribun Jambi memperkirakan masalah atau sumber masalah (diagnose cause) kebakaran hutan dan lahan adalah masyarakat sekitar dan perusahaan yang ingin membuka lahan dengan cara yang cepat. Mudahnya titik api meluas disebabkan oleh faktor alam di Provinsi Jambi yang intensitas hujannya mulai berkurang. Selain itu, kurang tegasnya pemerintah dalam penegakkan hukum menjadi faktor utama pelaku pembakaran lahan tidak memiliki rasa takut atau empati dalam membakar hutan dan lahan. (3). Tribun Jambi membuat keputusan moral dengan cara menonjolkan serta menghadirkan narasumber dari pihak pemerintah terkait upaya yang dilakukan dalam menjinakkan api yang muncul di berbagai wilayah. Pemerintah dijelaskan sudah berupaya dengan maksimal sehingga kabut asap bisa terhindar di tahun 2017. (4). Tribun Jambi menekankan penyelesaian (Treatment Recommendation) dengan menampilkan tindakan pemerintah dalam memberi hukuman, yakni denda 10 milyar dan penjara 10 tahun, sesuai 
dengan Undang-undang. Namun, Tribun Jambi masih menilai pemerintah masih kurang tegas, maka dari itu, pemerintah harus bertindak teda, dengan penarikan izin lahan. Pemerintah bisa mengambil lahan yang dibakar menjadi hak pemerintah guna memberikan efek jera pada perusahaan yang terlibat pembakaran hutan dan lahan.

\section{DAFTAR PUSTAKA}

Afdiningsih, F. L. S., Sihabudin, H. A., \& Praceka, P. A. (2017). Framing Pemberitaan Diskresi Ahok untuk Reklamasi Jakarta pada Majalah Tempo. Jurnal Kajian Jurnalisme, 1(1), 58-69. https://doi.org/10.24198/kj.v1i1.12229

Asteria, D. (2016). Optimalisasi Komunikasi Bencana Di Media Massa Sebagai Pendukung Manajemen Bencana. Jurnal Komunikasi Ikatan Sarjana Komunikasi Indonesia, 1(1), 1. https://doi.org/10.25008/jkiski.vli1.30

BNPB. (2017). Definisi dan Jenis Bencana. Retrieved November 5, 2017, from bnpb.go.id website: https://bnpb.go.id/home/definisi

Desri, H. (2016). Menyelesaikan Kebakaran Hutan dan Lahan (KARHUTLA) di Indonesia melalui "Jalan Pantas" atau "Jalan Pintas"? Seminar Nasional Hukum, 2(1), 277-292. https://doi.org/10.15294/SNH.V2I01.21312

DW. (2015, September 15). Lima Penyakit Yang Disebabkan Kabut Asap. Dw.Com, p. IPTEK. Retrieved from https://www.dw.com/id/lima-penyakit-yang-disebabkan-kabutasap/g-18715327

Eriyanto. (2012). Analisis Framing: Konstruksi, Ideologi, dan Politik Media. Yogyakarta: LKiS.

InfoDATIN. (2015). Masalah Kesehatan Akibat Kabut Asap Kebakaran Hutan dan Lahan Tahun 2015 (pp. 1-8). pp. 1-8. Jakarta: Kementerian Kesehatan RI.

Istiqomah. (2019). Pengaruh Pemberitaan Bencana Alam di Harian Serambi Indonesia Terhadap Kesadaran Masyarakat. Jurnal Studi Komunikasi (Indonesian Journal of Communications Studies), 3(1), 57. https://doi.org/10.25139/jsk.v3i1.1423

Kemenkes RI. (2016). Pusat Krisis Kesehatan Tahun 2015. Jakarta: Kementerian Kesehatan RI.

Nugraha, I. (2019). Kebakaran Hutan dan Lahan Sampai September 2019 Hampir 900 Ribu Hektar. Retrieved from mongabay.co.id website: https://www.mongabay. co.id/2019/10/22/kebakaran-hutan-dan-lahan-sampai-september-2019-hampir-900-ribuhektar/

Nursanto, H. A. (2016). Analisis wacana isu kebakaran hutan dan lahan indonesia di media massa. Institut Pertanian Bogor.

Pujiono. (2015, September 25). Mengapa kebakaran lahan gambut sulit dipadamkan. Beritagar. Id.

Qudratullah. (2016). Peran Dan Fungsi Komunikasi Massa. Jurnal Dakwah Tabligh, 17(2), 41-46. https://doi.org/10.24252/jdt.v17i2.6024

Santoso, P. (2016). KONSTRUKSI SOSIAL MEDIA MASSA. Al-Balagh, 1(1), 30-48.

Siregar, A. (1998). Bagaimana Meliput dan Menulis Berita Untuk Media Massa (Edisi 1). Yogyakarta: Kanisius.

Sobur, A. (2009). Analisis Teks Media: Suatu Pengantar untuk Analisis Wacana, Analisis Semiotik, dan Analisis Framing. Bandung: Remaja Rosdakarya.

Sumadiria, H. (2010). Jurnalistik Indonesia: Menulis Berita dan Feature. Bandung: Simbiosa Rekatama Media.

Suryani, A. S. (2012). Penanganan Asap Kabut Akibat Kebaran Hutan di Wilayah Perbatasan 
166 | Kajian Jurnalisme

Volume 03 Nomor 02 Tahun 2020

DOI: $10.24198 /$ jkj.v3i2.23894

Indonesia. Aspirasi, 3(1), 59-76.

Susanto, E. H., HH, S. B., Lucinda, Bintoro, A. G., Lestari, P., Chandra, A., ... Fajar, J. (2011). Komunikasi Bencana (A. Ishak, F. Junaedi, S. B. HH, \& A. Prabowo, Eds.). Yogyakarta: ASPIKOM, Buku Litera dan Perhumas.

Tacconi, L. (2003). Kebakaran hutan di Indonesia: penyebab, biaya dan implikasi kebijakan. In CIFOR Occasional Paper No. 38 (i). https://doi.org/10.17528/cifor/001200

Tamburaka, A. (2013). Agenda Setting Media Massa. Jakarta: Ra Grafindo.

Tribun Jambi. (2017). Tribun Jambi Terbaik 5 Tahun Berturut-turut. Jambi.Tribunnews. Com.

Walhi Jambi. (2016). MENEPUK AIR DIDULANG. TERPERCIK MUKA SENDIRI.

Retrieved February 27, 2018, from walhi-jambi.com website: https://www.walhi-jambi. com/2016/10/menepuk-air-didulang-terpercik-muka.html

Yanuary, D. A., \& Gumilar, G. (2018). Konstruksi Realitas Wartawan Pikiran Rakyat Mengenai Pengarusutamaan Isu Lingkungan. Jurnal Kajian Jurnalisme, 2(2), 235-250. https://doi. org/10.24198/kj.v2i2.21341 